\title{
Impact of Solid Content in the Electrospinning Solution on the Physical and Chemical Properties of Polyacrylonitrile (PAN) Nanofibrous Mats Vpliv koncentracije elektropredilne raztopine na fizikalne in kemijske lastnosti polikrilonitrilnih (PAN) nanovlaknatih kopren
}

\author{
Short scientific article/Kratki znanstveni prispevek \\ Received/Prispelo 06-2020 • Accepted/Sprejeto 08-2020
}

Corresponding author/Korespondenčna avtorica:

Prof. Dr. Dr. Andrea Ehrmann

E-mail: andrea.ehrmann@fh-bielefeld.de

\begin{abstract}
Polyacrylonitrile (PAN) belongs to the group of polymers that are often used for electrospinning, as it can be applied as a pre-cursor for carbon nanofibres and is spinnable from the low-toxic solvent dimethyl sulfoxide (DMSO). While the influence of different spinning parameters on fibre morphology and mass per unit area was investigated in a previous study, here we report on the impact of the spinning solution, using DMSO as a solvent and wire-based (needleless) electrospinning. Our results show that a broad range of solid contents can be applied, providing the opportunity to tailor the fibre diameter distribution or to optimize the areal weight of the nanofibrous mat by changing this parameter, while the chemical composition of the fibres remains identical. Keywords: needleless electrospinning, polyacrylonitrile (PAN), nanofibrous mat, dimethyl sulfoxide (DMSO), Fourier-transform infrared (FTIR) spectroscopy
\end{abstract}

Povzetek

Poliakrilonitril (PAN) spada med polimere, ki se pogosto uporabljajo za elektropredenje, saj ga lahko namenjajo za prekurzor ogljikovih nanovlaken in ker ga je mogoče presti iz nizkotoksičnega topila dimetil sulfoksida (DMSO). Medtem ko je bil vpliv različnih parametrov predenja na morfologijo vlaken in ploščinsko maso raziskan v prejšnji študiji, tukaj poročamo o vplivu predilne raztopine na osnovi topila DMSO in brezigelnega postopka elektropredenja. Naši rezultati kažejo, da je z uporabo širokega območja trdne snovi mogoče prilagajati porazdelitev premera vlaken ali optimizirati ploščinsko maso nanovlaknate koprene, medtem ko ostaja kemična sestava vlaken enaka. Ključne besede: brezigelno elektropredenje, poliakrilonitril (PAN), nanovlaknata koprena, dimetil sulfoksid (DMSO), Fourierjeva infrardeča spektroskopija s Fourierjevo transformacijo (FTIR)

\section{Introduction}

Electrospinning is a simple method used to prepare nanofibrous mats with fibre diameters in a typical range of several ten nanometres to a few micrometres $[1,2]$. While many research groups apply a nee- dle-based technique [3-5], needleless technologies are often easier to upscale to industrial production [6-8]. In such needleless techniques, a wire, a rotating cylinder or other free surfaces can be used as electrodes. In all technologies, a strong electric field concentrates electric charges along the polymer surface, resulting 
in the formation of so-called Taylor cones, and finally pulls drops of solution towards the counter electrode $[9,10]$. During this movement, the drop is severely stretched and thus forms a thin fibre when impinging on the substrate. From this description, it is already clear that not only spinning parameters - such as the voltage and the distance between the electrodes - influence the fibre formation process, but also environmental parameters, in particular the humidity in the spinning chamber, and finally the spinning solution itself [11-14].

An electrospinning technique facilitates the creation of nanofibres from a broad range of polymers and polymer blends [15-17], as well as combinations with non-polymeric materials [18-20]. Polyacrylonitrile (PAN) belongs to a group of highly interesting polymers, as it can be electrospun from the low-toxic solvent dimethyl sulfoxide (DMSO) and is often used as a precursor for carbon nanofibres $[14,19]$.

Such nanofibre mats can be used in a variety of applications, such as filters [21-23], tissue engineering and cell growth [24-26], catalysers [27, 28] and other technologies that are usually based on a large surface-to-volume ratio. For this reason, it is often important to tailor fibre diameters and possibly even fibre orientations according to the experimental necessities [29-31].

While the influence of the spinning parameters on fibre morphology and areal weight of PAN nanofibres produced using wire-based electrospinning was investigated in a previous study [32], here we report on the influence of the polymer content in the spinning solution on nanofibre diameter distribution, mass per unit area and the chemical composition of the resulting nanofibrous mat. In combination with the previous study, our findings facilitate the tailoring of these physical parameters by optimizing spinning and solution parameters.

\section{Materials and methods}

Samples were prepared using a "Nanospider Lab" needleless electrospinning machine (Elmarco Ltd., Liberec, Czech Republic). The spinning parameters were: voltage of $75 \mathrm{kV}$, nozzle diameter of $0.8 \mathrm{~mm}$, carriage speed of $100 \mathrm{~mm} / \mathrm{s}$, distance from bottom electrode to substrate of $240 \mathrm{~mm}$, distance from ground electrode to substrate of $50 \mathrm{~mm}$, temperature in the chamber of $21-22^{\circ} \mathrm{C}$, relative humidity in the chamber of $33 \%$, and a spinning duration of
10 minutes. The substrate is a static polypropylene nonwoven fabric, enabling a comparison of the areal weights of the electrospun nanofibrous mats with solid contents of the spinning solutions.

Spinning solutions were prepared with 12-22\% PAN dissolved in DMSO (min. 99.9\%; S3 Chemicals, Bad Oeynhausen, Germany). All percentages of PAN concentration given here refer to weight percentage. Lower solid contents ( $10 \%$ or less) resulted in pure electro-spraying without fibre formation, while higher solid contents ( $24 \%$ or more) were no longer spinnable. For lower solid contents $(12-14 \%$ in the case of relative humidity of just $31-32 \%$ in the spinning chamber and $16 \%$ in the case of relative humidity of $33-34 \%$ ), beads can be expected to form during electrospinning [14]. It should be mentioned that these values differ significantly from those that can be applied in the needle-based electrospinning of PAN, for which Wang et al. found values from $4 \%$ to $10 \%$ to be spinnable from the solvent dimethylformamide (DMF) [33].

Images of the nanofibrous mats were taken with a VK-8710 confocal laser scanning microscope (CLSM) (Keyence, Neu-Isenburg, Germany). Fibre diameters were evaluated using ImageJ $1.51 \mathrm{j} 8$ (National Institutes of Health, Bethesda, MD, USA), while fast Fourier transform (FFT) evaluations were performed using the same software. Such FFT images can be used to identify fibre alignment, which becomes visible as single lines in certain directions [31,34].

Chemical investigations were performed using an Excalibur 3100 Fourier transform infrared (FTIR) spectrometer (Varian Inc., USA). Solution viscosities were measured using a Brookfield Viscometer DV-II+ Pro dynamic viscometer. An LWT-01 conductivity test pen (Voltcraft) with a resolution of $10 \mu \mathrm{S} / \mathrm{cm}$ was used for conductivity measurements of the spinning solutions.

\section{Results and discussion}

The morphologies of the nanofibrous mats under investigation are depicted in Figure 1. For the three lowest solid contents $(12 \%, 14 \%$, and $16 \%)$, the images look very similar, showing a relatively regular nanofibre mat with some thick, long fibres on top that do not seem to be fully connected with the main part of the mat. Interestingly, under the environmental conditions used here, there is no strong bead formation visible. 
However, increasing the solid content to $18 \%$ clearly changes the morphology of the nanofibrous mat. Here, relatively long, thick and straight fibres are visible, apparently less connected and with larger pores than in the main part of the previously described samples. Such clearly visible fibres can also be derived by reducing the voltage to approximately $55-65 \mathrm{kV}$ for a solid content of $14-16 \%$, as previous experiments showed, but at the cost of a reduced areal weight [32].
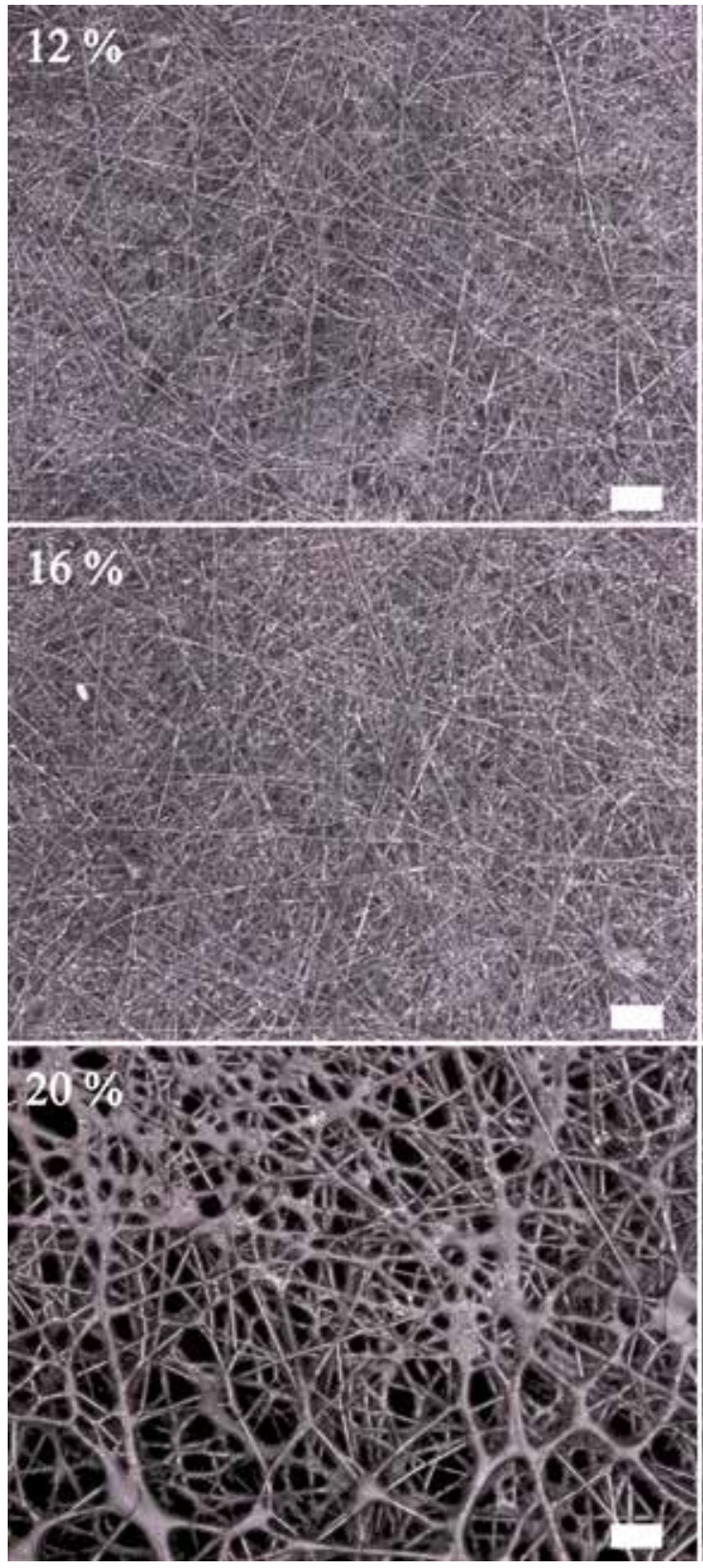

Figure 1: Representative CLSM images of PAN nanofibre mats, electrospun with identical spinning parameters from DMSO solutions with varying solid content. Scale bars indicate $10 \mu \mathrm{m}$.

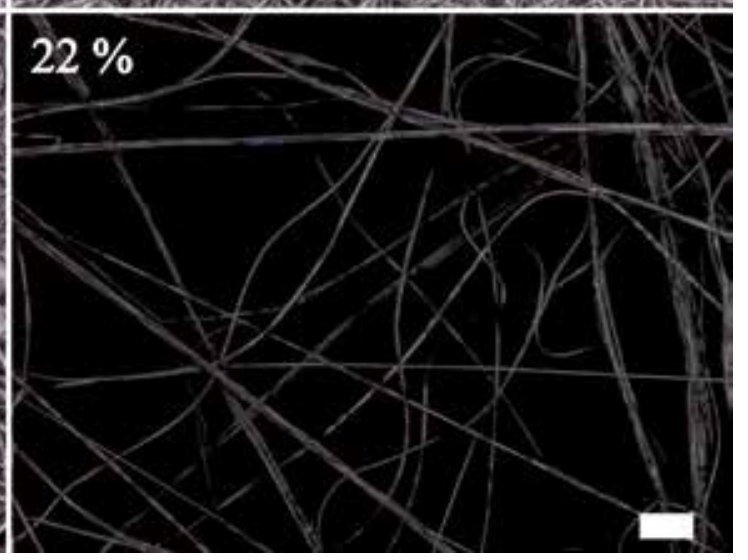

Increasing the solid content further to $20 \%$ unexpectedly resulted in even thicker fibres with strong conglutinations. Such a highly connected net could, for example, be useful for data transport through magnetic nanofibres [19] or in applications in which mechanical stability is essential, while the large pores and the reduced surface-to-volume ratio can be neglected.

Finally, for the highest solid content in the solution, it is obvious that only a few fibres are electrospun from
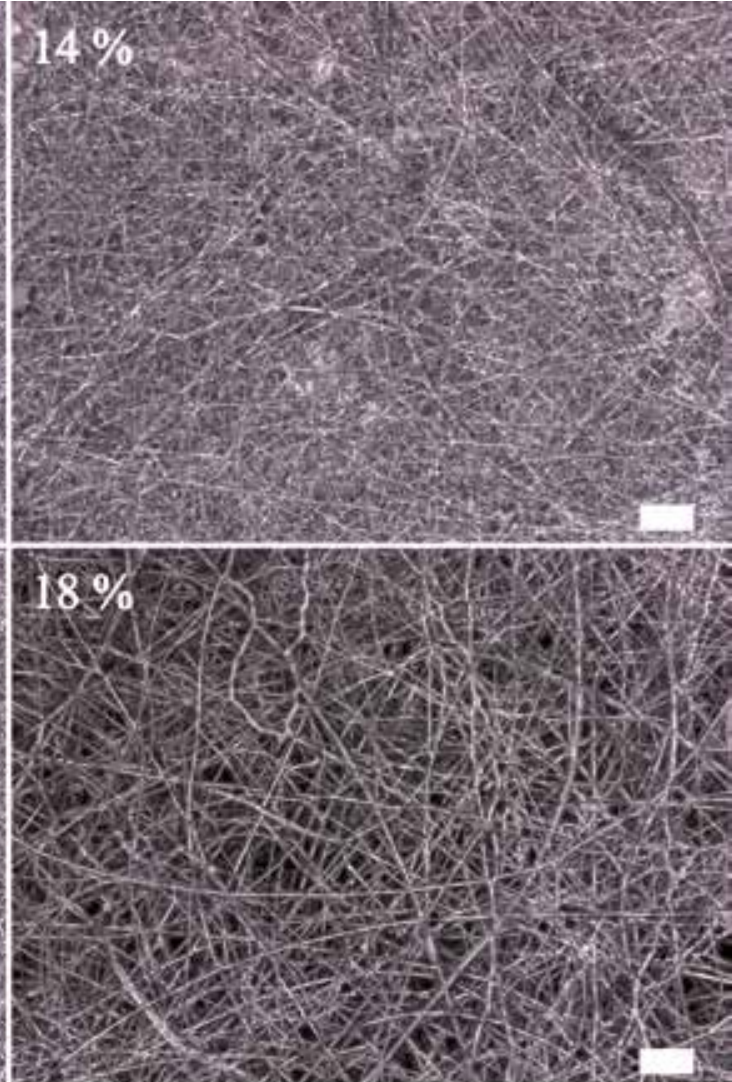

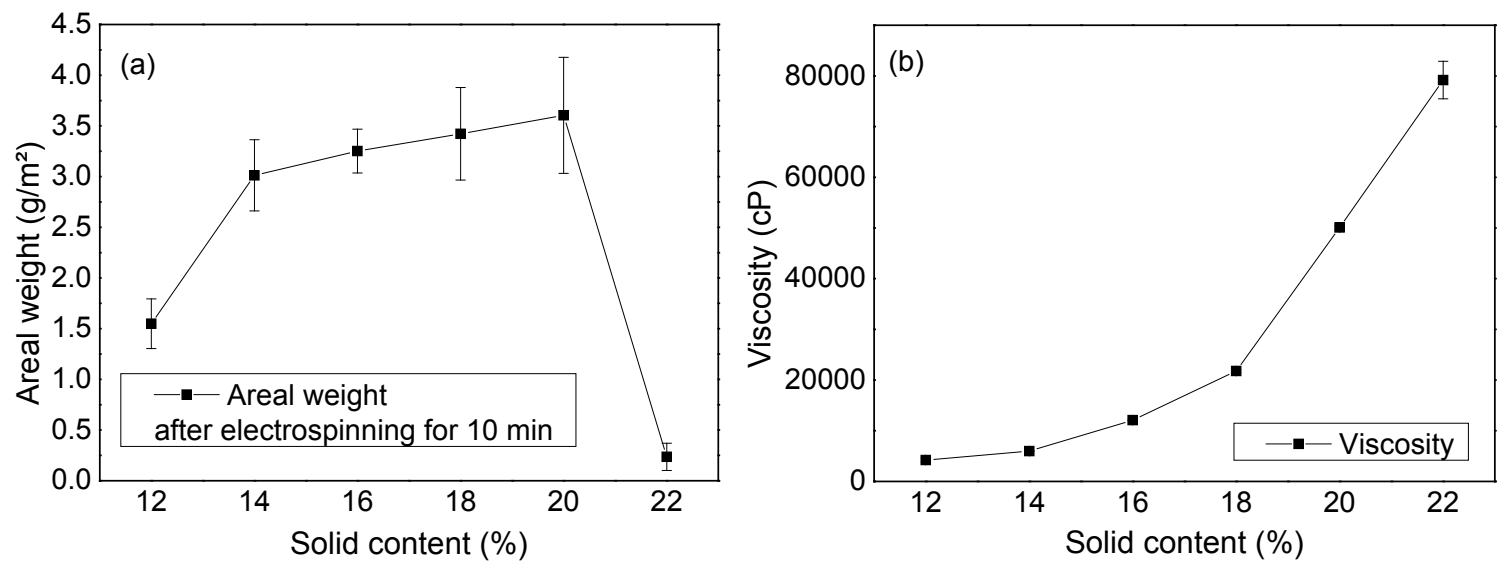

Figure 2: (a) Solid content dependence of the areal weight of the PAN nanofibrous mats under investigation; (b) dynamic viscosity of the corresponding spinning solutions

the solution with $22 \%$ PAN. This could also be observed during the spinning process where nearly no flying fibres were observed in the spinning chamber. It should be mentioned that additional FFT investigations (not shown here) supported the optical impression that the fibres do not show any angular orientation, corresponding to the expectation for a nanofibre mat electrospun on a static, fully non-conductive substrate.

Next, Figure 2a depicts the dependence of the areal weight on the solid content of the spinning solutions. While the curve increases sharply from $12 \%$ to $14 \%$ and almost linearly until $20 \%$, it drops suddenly towards a solid content of $22 \%$, as could already be expected from Figure 1. This is due to an increase in viscosity that exceeds the spinnability limit for the needleless spinning technique and no longer flows through the spinning nozzle properly. Viscosity values are given in Figure $2 b$ for comparison. It should be mentioned that solutions with solid contents of $12-20 \%$ behaved nearly fully Newtonian in the measured range of rotational speeds, which is why the error bars are too small to be visible. Only for the spinning solution with $22 \%$ PAN, is a slight increase of the dynamic viscosity with increasing rotational speed visible, i.e. the fluid becomes shear-thickening. Combining both figures suggests that a solid content of $16-18 \%$ should be ideal for the wire-based electrospinning of PAN from DMSO, thus giving relatively high material yields while still allowing for the modification of the nanofibre diameter distribution. It should be mentioned that the conductivity of the solutions was in the range of $30-50 \mu \mathrm{S} / \mathrm{cm}$ for all solutions, well below the maximum suggested conductivity of $10 \mathrm{mS} / \mathrm{cm}$ for the Nanospider, and thus can be expected to have no influence on the results of the spinning process.

The nanofibre diameter distribution is depicted in more detail in Figure 3. For the lower concentrations of $12-16 \%$, only a slight increase of the nanofibre diameter distribution is visible, with similar standard deviations, i.e. similar distribution widths. For a PAN content of 18\%, as could already be seen in Figure 1 , the diameter distribution is significantly shifted, while at the same time the standard deviation increases. Some fibres with larger diameters of around 750-1000 $\mathrm{nm}$ indicate that this PAN concentration is near to or slightly above the threshold below which a reliable fibre diameter distribution can be reached. This finding suggests further tests with solid contents of $17.0-17.5 \%$, which could possibly lead to a compromise between the clearly differentiated, long, straight fibres prepared with an $18 \%$ PAN concentration and the narrower diameter distribution achieved with smaller concentrations.

Finally, for concentrations of $20 \%$ and $22 \%$, the distributions become very broad, with large standard deviations that are unacceptable for many applications, clearly showing that the highest areal weight, achieved with a concentration of $20 \%$, comes at the cost of an undefined morphology of the nanofibrous mat.

The chemical composition of the nanofibre mats under investigation can be derived from the FTIR graphs in Figure 4. The typical PAN peaks represent the bending and stretching vibrations of $\mathrm{CH}_{2}$ at $2938 \mathrm{~cm}^{-1}, 1452 \mathrm{~cm}^{-1}$ and $1380 \mathrm{~cm}^{-1}$, stretching vibrations of the $\mathrm{C} \equiv \mathrm{N}$ nitrile functional group at $2240 \mathrm{~cm}^{-1}$, and the carbonyl $(\mathrm{C}=\mathrm{O})$ stretching peak at $1732 \mathrm{~cm}^{-1}$ [35]. 

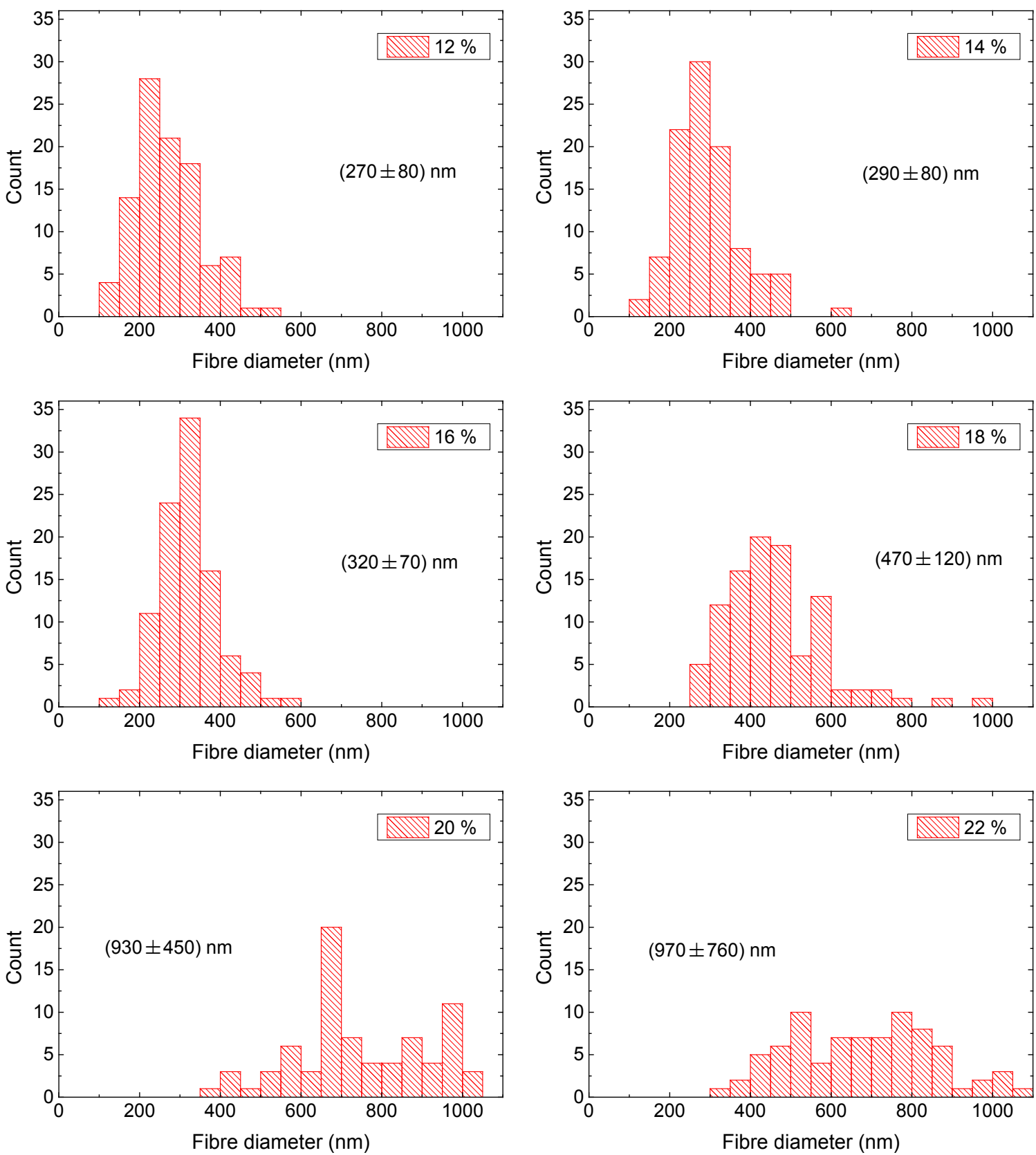

Figure 3: Fibre diameter distributions of nanofibrous mats, electrospun from solutions with different solid contents, for 100 fibres each. Insets show averages \pm standard deviations

The peaks not marked here in the ranges of 1250 $1230 \mathrm{~cm}^{-1}$ and $1090-1030 \mathrm{~cm}^{-1}$ belong to $\mathrm{C}-\mathrm{O}$ and $\mathrm{C}-\mathrm{O}-\mathrm{C}$ (ester) vibrations of co-monomers, such as itaconic acid or methyl acrylate, which are often added to PAN [35]. Around $2360-2320 \mathrm{~cm}^{-1}$, double-peaks are visible, which can sometimes be observed in FTIR measurements and are usually based on $\mathrm{CO}_{2}$ in gaseous and aqueous form [36], i.e. an artefact.
Besides these undesired effects, all PAN peaks look identical in all samples, which could be expected as the composition of the solid content of the spinning solutions remained unaltered. Small deviations between the heights of the peaks can be attributed to thickness deviations and air inclusion in the thin nanofibre mats, in this way varying the overall signal. This shows that the chemical composition of the PAN nanofibre mats remains unaltered when the solid content in the solution is varied. 


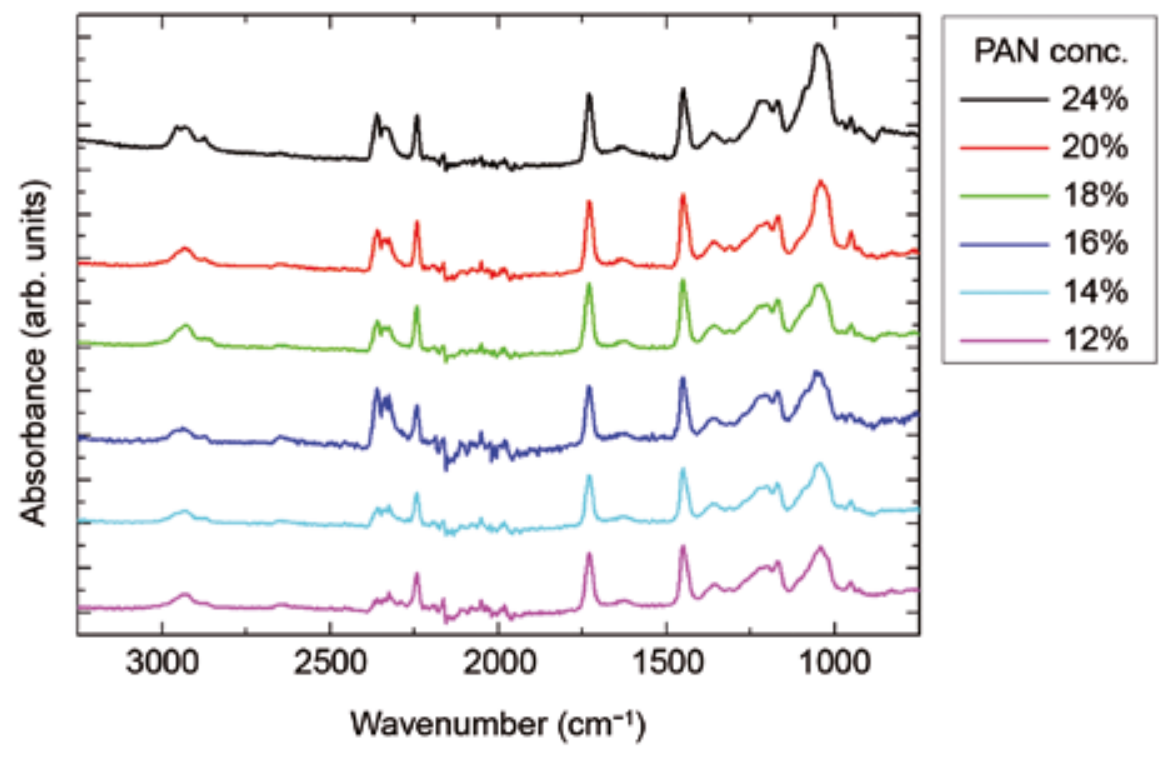

Figure 4: FTIR (Fourier transform infrared spectroscopy) graphs of nanofibrous mats, electrospun with different PAN concentrations, given in weight percentage

\section{Conclusion and outlook}

Needleless electrospinning of PAN from DMSO can be performed for a broad range of solid contents in the solution. Our investigations reveal that concentrations of between $14 \%$ and $18 \%$ are ideal for most applications, resulting in high material yields and narrow fibre diameter distributions, while facilitating the tailoring of the diameter to a certain extent. Higher concentrations of $20 \%$ result unexpectedly in conglutinated fibres, which may be interesting for certain applications in which mechanical strength is more important than the high surface-to-volume ratio of the nanofibrous mats produced at lower concentrations. A solid content of $22 \%$ is no longer spinnable, while a PAN concentration of $12 \%$ also resulted in a low material yield. For all samples under examination, the chemical composition remained unaltered.

Our study facilitates the identification of the optimum PAN concentrations for wire-based electrospinning, which are quite different from the optimal values for the needle-based technique.

Because PAN nanofibrous mats are often used as a precursor for carbon nanofibres, future investigations are necessary to examine the influence of the PAN concentration on the morphology and mechanical properties of carbonized nanofibrous mats, and on the carbon yield.

\section{References}

1. LI, Dan, XIA, Younan. Electrospinning of nanofibers : reinventing the wheel? Advanced Materials, 2004, 16(14), 1151-1170, doi: 10.1002/ adma.200400719.

2. RENEKER, Darell H., CHUN, Iksoo. Nanometre diameter fibres of polymer, produced by electrospinning. Nanotechnology, 1996, 7(3), 216-223, doi: 10.1088/0957-4484/7/3/009.

3. MACOSSAY, Javier, MARRUFFO, Alexis, RINCON, Roman, EUBANKS, Tom, KUANG, Anxiu. Effect of needle diameter on nanofiber diameter and thermal properties of electrospun poly(methyl methacrylate). Polymers for Advanced Technologies, 2007, 18(3), 180-183, doi: 10.1002/pat.844.

4. SUN, Z., ZUSSMANN, E., YARIN, A. L., WENDORFF, J. H., GREINER, A. Compound core-shell polymer nanofibers by co-electrospinning. Advanced Materials, 2003, 15(22), 1929-1932, doi: 10.1002/adma.200305136.

5. HEKMATI, Amir Houshang, RASHIDI, Abosaeed, GHAZISAEIDI, Reza, DREAN, JeanYves. Effect of needle length, electrospinning distance, and solution concentration on morphological properties of polyamide- 6 electrospun nanowebs. Textile Research Journal, 2013, 83(14), 1452-1466, doi: 10.1177/0040517512471746. 
6. WANG, Xin, NIU, Haitao, WANG, Xungai. Needleless electrospinning of nanofibers with a conical wire coil. Polymer Engineering \& Science, 2009, 49(8), 1582-1586, doi: 10.1002/pen.21377.

7. BANNER, Jana, DAUTZENBERG, Maria, FELDHANS, Theresa, HOFMANN, Julia, PLÜMER, Pia, EHRMANN, Andrea. Water resistance and morphology of electrospun gelatin blended with citric acid and coconut oil. Tekstilec, 2018, 61(2), 129-135, doi: 10.14502/ Tekstilec2018.61.129-135.

8. MAVER, Tina, KURECIC, Manja, PIVEC, Tanja, MAVER, Uros, GRADISNIK, Lidija, GASPARIC, Petra, KAKER, Barbara, BRATUSA, Ana, HRIBERNIK, Silvo, STANA KLEINSCHEK, Karin. Needleless electrospun carboxymethyl cellulose/polyethylene oxide mats with medicinal plant extracts for advanced wound care applications. Cellulose, 2020, 27(8), 4487-4508, doi: 10.1007/s10570-020-03079-9.

9. RENEKER, D. H., YARIN, A. L. Electrospinning jets and polymer nanofibers. Polymer, 2008, 49(10), 2387-2425, doi: 10.1016/j. polymer.2008.02.002.

10. YARIN, A. L., KOOMBHONGSE, S., RENEKER, D. H. Taylor cone and jetting from liquid droplets in electrospinning of nanofibers. Journal of Applied Physics, 2001, 90(9), 4836-4846, doi: 10.1063/1.1408260.

11. MIT-UPPATHAM, C., NITHITANAKUL, M., SUPAPHOL, P. Ultrafine electrospun polyamide- 6 fibers: effect of solution conditions on morphology and average fiber diameter. Macromolecular Chemistry and Physics, 2004, 205(17), 2327-2338, doi: 10.1002/ macp.200400225.

12. ZHANG, Jinning, SONG, Mingyu, LI, Dawei, YANG, Zhanping, CAO, Jianhua, CHEN, Yun, XU, Yang, WEI, Qufu. Preparation of self-clustering highly oriented nanofibers by needleless electrospinning methods. Fibers and Polymers, 2016, 17(9), 1414-1420, doi: 10.1007/s12221-016-6581-x.

13. LOMOS, S. V., MOLNAR, K. Compressibility of carbon fabrics with needleless electrospun PAN nanofibrous interleaves. Express Polymer Letters, 2016, 10(1), 25-35, doi: 10.3144/ expresspolymlett.2016.4.

14. SABANTINA, Lilia, BÖTTJER, Robin, WEHLAGE, Daria, GROTHE, Timo, KLÖCKER, Michaela, GARCÍA MATEOS, José, RODRÍGUEZ-MIRASOL, José, CORDERO,
Tomás, EHRMANN, Andrea. Morphological study of stabilization and carbonization of polyacrylonitrile/ $/ \mathrm{TiO}_{2}$ nanofiber mats. Journal of Engineered Fibers and Fabrics, 2019, 14, 1-8, doi: 10.1177/1558925019862242.

15. SEDGHI, Roya, SHAABANI, Alireza, SAYYARI, Nastaran. Electrospun triazole-based chitosan nanofibers as a novel scaffold for bone tissue repair and regeneration. Carbohydrate Polymers, 2020, 230, 1-12, doi: 10.1016/j.carbpol.2019.115707.

16. WORTMANN, Martin, FRESE, Natalie, SABANTINA, Lilia, PETKAU, Richard, KINZEL, Franziska, GÖLZHÄUSER, Armin, MORITZER, Elmar, HÜSGEN, Bruno, EHRMANN, Andrea. New polymers for needleless electrospinning from low-toxic solvents. Nanomaterials, 2018, 9(1), 1-11, doi: 10.3390/nano9010052.

17. MAVER, T., KURECIC, M., SMRKE, D. M., KLEINSCHEK, K. S., MAVER, U. Electrospun nanofibrous $\mathrm{CMC} / \mathrm{PEO}$ as a part of an effective pain-relieving wound dressing. Journal of Sol-Gel Science and Technology, 2016, 79(3), 475-486, doi: 10.1007/s10971-015-3888-9.

18. SISAKOVA, K., ORINAK, A., ORINAKOVA, R., STRECKOVA, M., PATERA, J., WELLE, A., KOSTECKA, Z., GIRMAN, V. Methane decomposition over modified carbon fibers as effective catalysts for hydrogen production. Catalysis Letters, 2020, 150(3), 781-793, doi: 10.1007/ s10562-019-02962-w.

19. FOKIN, Nadine, GROTHE, Timo, MAMUN, Al, TRABELSI, Marah, KLÖCKER, Michaela, SABANTINA, Lilia, DÖPKE, Christoph, BLACHOWICZ, Tomasz, HÜTTEN, Andreas, EHRMANN, Andrea. Magnetic properties of electrospun magnetic nanofiber mats after stabilization and carbonization. Materials, 2020, 13(7), 1-11, doi: 10.3390/ma13071552.

20. BLACHOWICZ, Tomasz, EHRMANN, Andrea. Recent developments in electrospun $\mathrm{ZnO}$ nanofibers: A short review. Journal of Engineered Fibers and Fabrics, 2020, 15, 1-6, doi: 10.1177/1558925019899682.

21. ROCHE, Remi, YALCINKAYA, Fatma. Electrospun polyacrylonitrile nanofibrous membranes for point-of-use water and air cleaning. ChemistryOpen, 2019, 8(1), 97-103, doi: 10.1002/ open.201800267.

22. LEMMA, Solomon Mengistu, ESPOSITO, Alfonso, MASON, Marco, BRUSETTI, Lorenzo, CESCO, Stefano, SCAMPICCHIO, Matteo. 
Removal of bacteria and yeast in water and beer by nylon nanofibrous membranes. Journal of Food Engineering, 2015, 157, 1-6, doi: 10.1016/j. jfoodeng.2015.02.005.

23. BOYRAZ, Evren, YALCINKAYA, Fatma, HRUZA, Jaku, MARYSKA, Jiri. Surface-modified nanofibrous PVDF membranes for liquid separation technology. Materials, 2019, 12(17), 1-12, doi: 10.3390/ma12172702.

24. DALTON, Paul D., KLINKHAMMER, Kristina, SALBER, Jochen, KLEE, Doris, MÖLLER, Martin. Dirct in vitro electrospinning with polymer melts. Biomacromolecules, 2006, 7(3), 686-690, doi: 10.1021/bm050777q.

25. WEHLAGE, Daria, BLATTNER, Hannah, SABANTINA, Lilia, BÖTTJER, Robin, GROTHE, Timo, RATTENHOLL, Anke, GUDERMANN, Frank, LÜTKEMEYER, Dirk, EHRMANN, Andrea. Sterilization of PAN/gelatin nanofibrous mats for cell growth. Tekstilec, 2019, 62(2), 78-88, doi: 10.14502/Tekstilec2019.62.78-88.

26. WEHLAGE, Daria, BLATTNER, Hannah, MAMUN, Al, KUTZLI, Ines, DIESTELHORST, Elise, RATTENHOLL, Anke, GUDERMANN, Frank, LÜTKEMEYER, Dirk, EHRMANN, Andrea. Cell growth on electrospun nanofiber mats from polyacrylonitrile (PAN) blends. AIMS Bioengineering, 2020, 7, 43-54, doi: 10.3934/ bioeng.2020004.

27. LIN, Kun-Yi Andrew, YANG, Ming-Tong, LIN, Jyun-Ting, DU, Yunchen. Cobalt ferrite nanoparticles supported on electrospun carbon fiber as a magnetic heterogeneous catalyst for activating peroxymonosulfate. Chemosphere, 2018, 208, 502-511, doi: 10.1016/j.chemosphere.2018.05.127.

28. GARCÍA-MATEOS, F. J., CORDEROLANZAC, T., BERENGUER, R., MORALLÓN, E., CAZORLA-AMORÓS, D., RODRÍGUEZMIRASOL, J., CORDERO, T. Lignin-derived Pt supported carbon (submicron)fiber electrocatalysts for alcohol electro-oxidation. Applied Catalysis B: Environmental, 2017, 211, 18-30, doi: 10.1016/j.apcatb.2017.04.008.

29. BIAN, Ye, WANG, Shijie, ZHANG, Li, CHEN, Chun. Influence of fiber diameter, filter thickness, and packing density on PM2.5 removal efficiency of electrospun nanofiber air filters for indoor applications. Building and Environment, 2020, 170, 1-9, doi: 10.1016/j.buildenv.2019.106628.

30. NIKBAKHT, Mohammad, SALEHI, Majid, REZAYAT, Seyed Mahdi, MAJIDI, Reza Faridi. Various parameters in the preparation of chitosan/polyethylene oxide electrospun nanofibers containing Aloe vera extract for medical applications. Nanomedicine Journal, 2020, 7(1), 21-28, doi: 10.22038/nmj.2020.07.03.

31. BAZRAFSHAN, Zahra, STYLIOS, George K. Custom-built electrostatics and supplementary bonding in the design of reinforced Collagen-g-P (methyl methacrylate-co-ethyl acrylate)/ nylon 66 core-shell fibers. J. Mech. Behav. Biomed. Mater., 2018, 87, 19-29, doi: 10.1016/j.jmbbm.2018.07.002.

32. SABANTINA, Lilia, RODRÍGUEZ-MIRASOL, José, CORDERO, Tomás, FINSTERBUSCH, Karin, EHRMANN, Andrea. Investigation of needleless electrospun PAN nanofiber mats. AIP Conference Proceedings, 2018, 1952, 020085, doi: 10.1063/1.5032047.

33. WANG, Ran, LIU, Yang, LI, Brandon, HSIAO, Benjamin S., CHU, Benjamin. Electrospun nanofibrous membranes for high flux microfiltration. Journal of Membrane Science, 2012, 392-393, 167-174, doi: 10.1016/j.memsci.2011.12.019.

34. STORCK, Jan Lukas, GROTHE, Timo, MAMUN, Al, SABANTINA, Lilia, KLÖCKER, Michaela, BLACHOWICZ, Tomasz, EHRMANN, Andrea. Orientation of electrospun magnetic nanofibers near conductive areas. Materials, 2019, 13(1), 1-14, doi: 10.3390/ma13010047.

35. MÓLNAR, Kolos, SZOLNOKI, Beáta, TOLDY, Andrea, VAS, László Mihály. Thermochemical stabilization and analysis of continuously electrospun nanofibers. J. Therm. Anal. Calorim., 2014, 117(3), 1123-1135, doi: 10.1007/ s10973-014-3880-6.

36. SCHÄDLE, Thomas, PEJCIC, Bobby, MIZAIKOFF, Boris. Monitoring dissolved carbon dioxide and methane in brine environments at high pressure using IR-ATR spectroscopy. Analytical Methods, 2016, 8(4), 756-762, doi: 10.1039/c5ay02744f. 